\title{
Enantioselective Potentiometric Membrane Electrodes Based on Antibiotics for the Determination of L- and D-Glyceric Acids
}

\author{
Raluca-Ioana Stefan-van Staden, ${ }^{1}$ R'afat M. Nejem, ${ }^{2}$ Jacobus Frederick van Staden, ${ }^{1}$ \\ and Hassan Y. Aboul-Enein ${ }^{3}$ \\ ${ }^{1}$ Laboratory of Electrochemistry and PATLAB Bucharest, National Institute of Research for Electrochemistry and Condensed Matter, \\ 202 Splaiul Independentei Strada, 060021 Bucharest, Romania \\ ${ }^{2}$ Department of Chemistry, Al-Aqsa University, Gaza, Palestine \\ ${ }^{3}$ The Pharmaceutical and Drug Industries Research Division, Pharmaceutical and Medicinal Chemistry Department, \\ National Research Centre, Dokki, Cairo 12311, Egypt \\ Correspondence should be addressed to Raluca-Ioana Stefan-van Staden, iustinavanstaden@yahoo.com
}

Received 9 February 2011; Accepted 16 March 2011

Academic Editor: Bengi Uslu

Copyright (c) 2011 Raluca-Ioana Stefan-van Staden et al. This is an open access article distributed under the Creative Commons Attribution License, which permits unrestricted use, distribution, and reproduction in any medium, provided the original work is properly cited.

Glyceric acid (GA) is a human metabolite existing in L- and D-configurations, which are considered the markers for the diseases L- and D-glyceric aciduria/academia, respectively. Enantioselective, potentiometric membrane electrodes based on carbon paste modified with antibiotics as chiral selectors, vancomycin, and teicoplanin were designed for the assay of L- and D-GA, respectively, in the concentration ranges of $10^{-9}-10^{-7}$ and $10^{-4}-10^{-2} \mathrm{moL} / \mathrm{L}$ with very low detection limits $\left(1.5 \times 10^{-10} \mathrm{moL} / \mathrm{L}\right.$ for L-GA and $1.6 \times 10^{-4} \mathrm{moL} / \mathrm{L}$ for D-GA, resp.). The surface of the electrodes can be regenerated simply by polishing in order to obtain a fresh surface ready to be used in a new assay. The proposed electrodes can be successfully applied for the enantioanalysis of L- and D-glyceric acids in serum samples.

\section{Introduction}

The enantiomers of the urinary organic acids are important markers for inborn errors of metabolism. Accordingly, there is a growing demand for determining the metabolic products in human blood (academia) and urine (aciduria). Different enantiomers may originate from separate metabolic pathway, due to enzyme deficiency.

Glyceric acid (2,3-dihydroxypropionic acid, GA) is a human metabolite existing in L- and D-configurations. These two enantiomers are vital biological markers for the diagnosis of two different metabolic diseases, primary hyperoxaluria type II (L-glyceric aciduria, $\mathrm{PH} 2$ ) and $\mathrm{D}$-glyceric aciduria [1-6]. Therefore, enantioselective analysis of glyceric acid is necessary to differentiate between the two inherited metabolic diseases.

Up to date, the assay of GA was done using capillary gas chromatography [7-10], liquid chromatography [11], high-performance liquid chromatography [12], capillary electrophoresis [13], polarimetry [14], and colorimetric methods [15].

Enantioselective, potentiometric membrane electrodes (EPMEs) proved to be very reliable for the enantioanalysis of pharmaceutical compounds as well as of compounds of clinical importance [16]. Macrocyclic antibiotics represent a new class of chiral selectors used in the design of EPME, offering a high selectivity and enantioselectivity [17]. The macrocyclic antibiotics contain stereogenic centers and functional groups, which allow them to interact with chiral molecules by hydrophobic, dipole-dipole, $\pi-\pi$ interactions, hydrogen bonding, steric repulsion $[18,19]$, and charge-tocharge repulsions [20-22].

This paper describes the design, response characteristics, (enantio) selectivity, and applications of two EPMEs based on vancomycin and teicoplanin for the enantioanalysis of GA. 
TABLE 1: Response characteristics of enantioselective, potentiometric membrane electrodes for L- and D-glyceric acids ${ }^{\mathrm{a}}$.

\begin{tabular}{lcccc}
\hline EPME based on & $\begin{array}{c}\text { Slope } \\
\text { (mV/decade of concentration })\end{array}$ & $\begin{array}{c}\text { Parameters } \\
\text { Intercept, } \mathrm{E}^{\mathrm{o}} \\
(\mathrm{mV})\end{array}$ & $\begin{array}{c}\text { Linear range } \\
(\mathrm{moL} / \mathrm{L})\end{array}$ & $\begin{array}{c}\text { Detection limit } \\
(\mathrm{moL} / \mathrm{L})\end{array}$ \\
\hline Vancomycin & 58.6 & 574.6 & $10^{-9}-10^{-7}$ & $1.56 \times 10^{-10}$ \\
Teicoplanin & 50.0 & 206.0 & $10^{-4}-10^{-2}$ & $7.60 \times 10^{-5}$ \\
\hline
\end{tabular}

${ }^{a}$ All measurements were made at $25^{\circ} \mathrm{C}$; all values are the average of ten determinations.

\section{Experimental}

2.1. Electrode Design. Paraffin oil and graphite powder were mixed in a ratio of $1: 4(\mathrm{w} / \mathrm{w})$ to form the carbon paste. The modified carbon pastes were obtained by the addition of the aqueous solutions of vancomycin $(\mathrm{pH}=4)$ or teicoplanin $(\mathrm{pH}=6)\left(10^{-3} \mathrm{moL} / \mathrm{L}\right)(100 \mu \mathrm{L}$ chiral selector solution to $100 \mathrm{mg}$ carbon paste) to the carbon paste. The unmodified carbon paste was filled into a plastic pipette peak leaving a space of 3-4 mm into the top to be filled with the modified carbon paste.

The diameter of the proposed EPMEs was $3 \mathrm{~mm}$. Electric contact was obtained by inserting an $\mathrm{Ag} / \mathrm{AgCl}$ wire into the carbon paste. $0.1 \mathrm{moL} / \mathrm{L} \mathrm{KCl}$ was used as internal solution. All the sensors tips were gently rubbed on fine abrasive paper to produce a flat surface. The surface of the sensors was wetted with deionized water and then polished with an alumina paper (polished strips 30144-011, Orion) before use. When not in use, the electrodes were immersed in $10^{-3} \mathrm{moL} / \mathrm{L}$ of L- or D-glyceric acid solution, respectively.

2.2. Apparatus. A 663 VA Stand (Metrohm, Herisau, Switzerland) connected to a PGSTAT 100 and software (Eco Chemie version 4.9) was used for all potentiometric measurements. $\mathrm{An} \mathrm{Ag} / \mathrm{AgCl}(0.1 \mathrm{moL} / \mathrm{L} \mathrm{KCl})$ electrode was used as reference electrode in the cell.

2.3. Reagents and Materials. L- and D-glyceric acids, vancomycin, and teicoplanin were purchased from SigmaAldrich (USA). Graphite powder $(1-2 \mu \mathrm{m})$ was purchased from Aldrich (Milwaukee, WI, USA); paraffin oil was purchased from Fluka (Buchs, Switzerland), and phosphate buffer $(\mathrm{pH}=3.5)$ from Merck (Darmstadt, Germany).

Deionized water from a Modulab system (Continental Water Systems, San Antonio, Tex, USA) was used for all solutions preparation. $\mathrm{L}$ - and D-glyceric acid solutions were prepared from standard L- and D-GA solutions $(1 \times$ $10^{-1} \mathrm{moL} / \mathrm{L}$ ) by serial dilutions. Serum and urine samples were buffered with phosphate buffer $(\mathrm{pH}=3.5)$, sample $:$ buffer $=1: 1$.

2.4. Recommended Procedure. Direct potentiometry was used for potential determination of each standard solution $\left(10^{-10}-10^{-2} \mathrm{moL} / \mathrm{L}\right)$. All measurements were performed at $25^{\circ} \mathrm{C}$. The electrodes were placed in stirred standard solutions. Calibration graphs were obtained by plotting
$\mathrm{E}(\mathrm{mV})$ versus pL-GA or $\mathrm{pD}-\mathrm{GA}$, respectively. The unknown concentrations were determined from the calibration graphs.

\section{Results and Discussion}

3.1. EPMEs Response Characteristics. The response characteristics of the EPMEs were determined at $\mathrm{pH}=3.5$ (phosphate buffer) using the potentiometric method. The response obtained for L-GA was linear and near-Nernstian only for the EPME based on vancomycin, while the response obtained for D-GA was linear and near-Nernstian only for the EPME based on teicoplanin. The following are the equations of calibration for the EPMEs based on vancomycin and teicoplanin:

$$
\begin{aligned}
& \text { L-GA: } \mathrm{E}=574.6-58.6 \mathrm{pL}-\mathrm{GA}, \quad r=0.9957, \\
& \text { D-GA: } \mathrm{E}=206.0-50.0 \mathrm{pD}-\mathrm{GA}, \quad r=0.9988,
\end{aligned}
$$

where $\mathrm{E}(\mathrm{mV})$ is the potential of the electrochemical cell, $\mathrm{pL}-\mathrm{GA}=-\log [\mathrm{L}-\mathrm{GA}], \mathrm{pD}-\mathrm{GA}=-\log [\mathrm{D}-\mathrm{GA}]$, and $r$ is the correlation coefficient. The response characteristics of the EPMEs are shown in Table 1. A very low detection limit was recorded for the assay of L-GA: $10^{-10} \mathrm{moL} / \mathrm{L}$ magnitude order. The electrodes responses displayed a good stability and reproducibility for the tests performed for 3 months, when daily used for measurements (RSD $<1.0 \%$ ).

The response time recorded for the assay of the Denantiomer was $2 \mathrm{~min}$ while the response time recorded for the assay of the L-enantiomer was $30 \mathrm{~s}$.

3.2. The Influence of $p H$ on the Responses of the Electrodes. The effect of $\mathrm{pH}$ on the response of the electrodes was determined by recording the emf of the cell containing solutions of $\mathrm{L}$ - or D-GA of different $\mathrm{pH}$ values. The $\mathrm{pHs}$ of the solutions of the enantiomers were adjusted using small volumes of $\mathrm{HCl}(0.1 \mathrm{moL} / \mathrm{L})$ or $\mathrm{NaOH}(0.1 \mathrm{moL} / \mathrm{L})$ solutions. $\mathrm{E}(\mathrm{mV})$ versus $\mathrm{pH}$ plots (Figure 1 ) show that the emf is not depending on the $\mathrm{pH}$ in the ranges of 4-9 and 3-8 for vancomycin- and teicoplanin-based EPME, respectively.

3.3. Selectivity of the Electrode. The selectivity of both electrodes was checked using the mixed solutions method proposed by Ren [23], over L- or D-GA, creatine, and creatinine. The ratios between the concentrations of analyte and interferent were $1: 10$. The potentiometric selectivity coefficients (Table 2) obtained for EPMEs proved their 


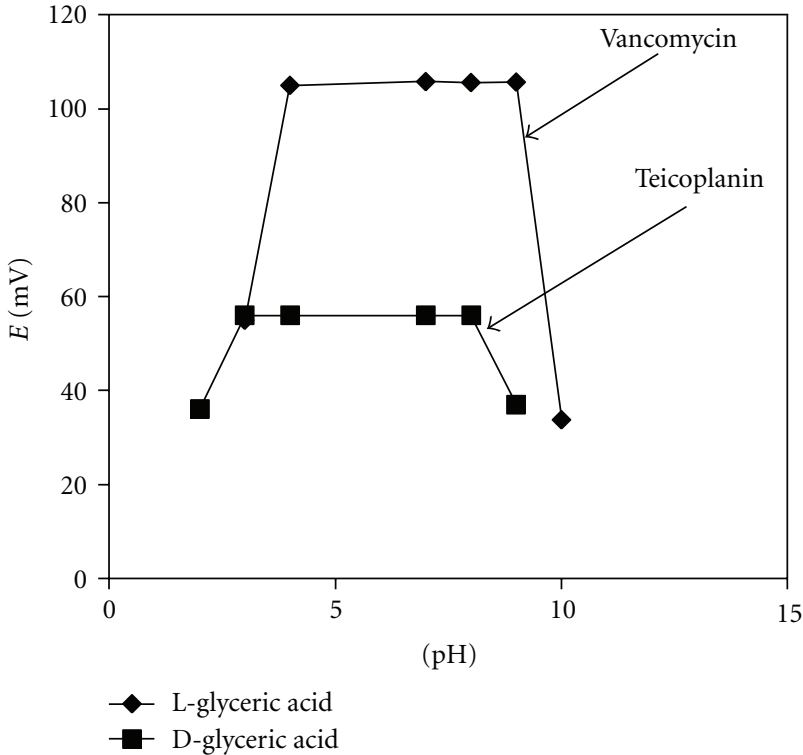

Figure 1: Effect of $\mathrm{pH}$ on the response of the EPMEs to Lglyceric acid $\left(10^{-8} \mathrm{moL} / \mathrm{L} \mathrm{L}-\mathrm{GA}\right)$ and $\mathrm{D}$-glyceric acid $\left(10^{-3} \mathrm{moL} / \mathrm{L}\right)$ solutions. (I) Vancomycin-based EPME; (II) teicoplanin-based EPME.

TABle 2: Potentiometric selectivity coefficients for the electrodes proposed for the assay of $\mathrm{L}$ - and D-glyceric acids ${ }^{\mathrm{a}}$.

\begin{tabular}{|c|c|c|}
\hline \multirow[t]{2}{*}{ Interference species $(\mathrm{J})$} & \multicolumn{2}{|c|}{$\begin{array}{c}\mathrm{pK}_{\mathrm{sel}}^{\mathrm{pot}} \\
\text { EPME based on }\end{array}$} \\
\hline & Vancomycin & Teicoplanin \\
\hline L-GA & - & 2.39 \\
\hline D-GA & 2.41 & - \\
\hline Creatine & 2.09 & 2.08 \\
\hline Creatinine & 2.41 & 2.39 \\
\hline
\end{tabular}

TABLE 3: The results obtained for the determination of L-glyceric acid in the presence of D-glyceric acid ${ }^{\mathrm{a}}$.

\begin{tabular}{ll}
\hline $\begin{array}{l}\mathrm{L}: \mathrm{D} \\
(\mathrm{moL} / \mathrm{moL})\end{array}$ & Recovery, $\%$ \\
\hline $2: 1$ & $99.25 \pm 0.01$ \\
$1: 1$ & $99.75 \pm 0.02$ \\
$1: 2$ & $99.26 \pm 0.06$ \\
$1: 4$ & $99.30 \pm 0.04$ \\
$1: 9$ & $99.67 \pm 0.06$ \\
\hline
\end{tabular}

${ }^{a}$ All measurements were made at $25^{\circ} \mathrm{C}$; all values are the average of ten determinations.

enantioselectivity as well as their selectivity over creatine and creatinine. Inorganic cations such $\mathrm{Na}^{+}, \mathrm{K}^{+}$, and $\mathrm{Ca}^{2+}$ do not interfere in the analysis of $\mathrm{L}-$ and $\mathrm{D}-\mathrm{GA}$.

3.4. Analytical Applications. Solutions containing L- and DGA in different ratios were prepared to test the recovery
TABLE 4: The results obtained for the determination of D-glyceric acid in the presence of L-glyceric acid ${ }^{\mathrm{a}}$.

\begin{tabular}{ll}
\hline $\begin{array}{l}\mathrm{D}: \mathrm{L} \\
(\mathrm{moL} / \mathrm{moL})\end{array}$ & Recovery, \% \\
\hline $2: 1$ & $99.96 \pm 0.04$ \\
$1: 1$ & $99.57 \pm 0.03$ \\
$1: 2$ & $99.99 \pm 0.03$ \\
$1: 4$ & $99.95 \pm 0.02$ \\
$1: 9$ & $99.93 \pm 0.03$ \\
\hline
\end{tabular}

all measurements were made at $25^{\circ} \mathrm{C}$; all values are the average of ten determinations.

TABLE 5: Recovery of L-glyceric acid in serum and urine samples, $(\%)^{\mathrm{a}}$.

\begin{tabular}{lccc}
\hline \multirow{2}{*}{$\begin{array}{l}\text { Type of } \\
\text { sample }\end{array}$} & Sample no. & \multicolumn{2}{c}{ \% Recovery, L-GA } \\
\hline \multirow{3}{*}{ Serum samples } & 1 & 98.47 & $98.52 \pm 0.04$ \\
& 2 & 98.15 & $98.08 \pm 0.08$ \\
& 3 & 98.02 & $98.00 \pm 0.06$ \\
\hline \multirow{3}{*}{ Urine samples } & 4 & 99.30 & $99.25 \pm 0.02$ \\
& 5 & 99.50 & $99.49 \pm 0.03$ \\
& 7 & 99.45 & $99.50 \pm 0.03$ \\
& 8 & 99.86 & $99.87 \pm 0.02$ \\
& 9 & 99.12 & $99.13 \pm 0.01$ \\
\hline
\end{tabular}

all measurements were made at $25 \circ \mathrm{C}$; all values are the average of ten determinations.

TABLE 6: Recovery of D-glyceric acid in serum and urine samples, $(\%)^{\mathrm{a}}$.

\begin{tabular}{lccc}
\hline $\begin{array}{l}\text { Type of } \\
\text { sample }\end{array}$ & Sample no. & \multicolumn{2}{c}{ \% Recovery, D-GA } \\
Serum samples & 10 & 97.20 & $97.23 \pm 0.02$ \\
& 11 & 96.70 & $96.65 \pm 0.03$ \\
& 12 & 97.70 & $97.21 \pm 0.08$ \\
\hline \multirow{4}{*}{ Urine samples } & 13 & 99.20 & $99.18 \pm 0.02$ \\
& 14 & 99.50 & $99.48 \pm 0.01$ \\
& 16 & 99.93 & $100.00 \pm 0.02$ \\
& 17 & 99.43 & $99.40 \pm 0.03$ \\
& 18 & 99.15 & $99.12 \pm 0.02$ \\
\hline
\end{tabular}

all measurements were made at $25^{\circ} \mathrm{C}$; all values are the average of ten determinations.

for each enantiomer in the presence of its antipode and the suitability of the EPMEs for the enantioanalysis of L- and DGA in serum and urine samples. The recovery tests (Tables 3 and 4) obtained for each enantiomer proved the suitability of the electrodes for enantioanalysis. No significant differences in the recovery values were recorded for the ratios between $\mathrm{L}: \mathrm{D}$ or $\mathrm{D}: \mathrm{L}$ enantiomers varying from $1: 9$ to $1: 99.99$. 
The results obtained for the analysis of L-glyceric and D-glyceric acid in serum and urine samples are shown in Tables 5 and 6, respectively. Different serum samples and urine samples were collected from different patients suspected of L-glyceric academia (1-3) or aciduria (4-9) and D-glyceric academia (10-12) or aciduria (13-18) for the recovery of L- and D-glyceric acid. All the serum and urine samples were buffered with phosphate buffer $\mathrm{pH}=$ 3.5. The results obtained using the proposed EPMEs are in good concordance with those obtained using the standard method, which is an HPLC technique [24]. The advantage of the proposed method over the standard one was the high reliability measured through low values of RSD (\%), short time of analysis, and low cost of the enantioanalysis.

\section{Conclusions}

The macrocyclic antibiotics vancomycin and teicoplanin proved to be viable chiral selectors for the design of EPMEs. The enantioselective, potentiometric membranes electrodes proposed can be reliably used for the enantioselective analyses of L- and D-glyceric acids in serum and urine samples. Accordingly, they can be used for the fast and reliable diagnosis of $\mathrm{L}$ - or D-glyceric academia/aciduria. The construction of the electrodes is simple, fast, and reproducible. The serum and urine samples need only to be buffered with phosphate buffer of $\mathrm{pH}$ of 3.5 before L- and D-glyceric acids were determined.

\section{References}

[1] H. E. Williams and L. H. Smith Jr., "L-glyceric aciduria. A new genetic variant of primary hyperoxaluria," The New England Journal of Medicine, vol. 278, no. 5, pp. 233-238, 1968.

[2] E. Van Schaftingen, "D-Glycerate kinase deficiency as a cause of D-glyceric aciduria," The FEBS Letters, vol. 243, no. 2, pp. 127-131, 1989.

[3] S. K. Wadman, M. Duran, and D. Ketting, "D glyceric acidemia in a patient with chronic metabolic acidosis," Clinica Chimica Acta, vol. 71, no. 3, pp. 477-484, 1976.

[4] N. J. Brandt, S. Brandt, K. Rasmussen, and F. Schnoheyder, "Letter: hyperglycericacidaemia with hyperglycinaemia: a new inborn error of metabolism," British Medical Journal, vol. 4, no. 5940, pp. 344-347, 1974.

[5] E. Van Schaftingen, J. P. Draye, and F. Van Hoof, "Coenzyme specificity of mammalian liver D-glycerate dehydrogenase," European Journal of Biochemistry, vol. 186, no. 1-2, pp. 355359, 1989.

[6] P. D. Dawkins and F. Dickens, "The oxidation of d- and 1glycerate by rat liver," The Biochemical Journal, vol. 94, pp. 353-367, 1965.

[7] A. Kaunzinger, A. Rechner, T. Beck, A. Mosandl, A. C. Sewell, and H. Böhles, "Chiral compounds as indicators of inherited metabolic disease: simultaneous stereodifferentiation of lactic, 2-hydroxyglutaric- and glyceric acid by enantioselective cGC," Enantiomer, vol. 1, no. 3, pp. 177-182, 1996.

[8] J. P. Kamerling, G. J. Gerwig, J. F. G. Vliegenthart, M. Duran, D. Ketting, and S. K. Wadman, "Determination of the configurations of lactic and glyceric acids from human serum and urine by capillary gas-liquid chromatography," Journal of Chromatography B, vol. 143, no. 2, pp. 117-123, 1977.
[9] D. J. Dietzen, T. R. Wilhite, D. N. Kenagy, D. S. Milliner, C. H. Smith, and M. Landt, "Extraction of glyceric and glycolic acids from urine with tetrahydrofuran: utility in detection of primary hyperoxaluria," Clinical Chemistry, vol. 43, no. 8, pp. 1315-1320, 1997.

[10] M. Petrarulo, C. Vitale, P. Facchini, and M. Marangella, "Biochemical approach to diagnosis and differentiation of primary hyperoxalurias: an update," Journal of Nephrology, vol. 11, supplement 1, pp. 23-28, 1998.

[11] M. S. Rashed, H. Y. Aboul-Enein, M. Alamoudi et al., "Chiral liquid chromatography tandem mass spectrometry in the determination of the configuration of glyceric acid in urine of patients with D-glyceric and L-glyceric acidurias," Biomedical Chromatography, vol. 16, no. 3, pp. 191-198, 2002.

[12] M. Petrarulo, M. Marangella, D. Cosseddu, and F. Linari, "High-performance liquid chromatographic assay for Lglyceric acid in body fluids. Application in primary hyperoxaluria type 2," Clinica Chimica Acta, vol. 211, no. 3, pp. 143153, 1992.

[13] A. García, M. Muros, and C. Barbas, "Measurement of nephrolithiasis urinary markers by capillary electrophoresis," Journal of Chromatography B, vol. 755, no. 1-2, pp. 287-295, 2001.

[14] M. Fontaine, N. Porchet, C. Largilliere et al., "Biochemical contribution to diagnosis and study of a new case of D-glyceric acidemia/aciduria," Clinical Chemistry, vol. 35, no. 10, pp. 2148-2151, 1989.

[15] G. R. Bartlett, "Human red cell glycolytic intermediates," The Journal of Biological Chemistry, vol. 234, no. 3, pp. 449-458, 1959.

[16] R. I. Stefan, J. F. van Staden, and H. Y. Aboul-Enein, Electrochemical Sensors in Bioanalysis, Marcel Dekker, New York, NY, USA, 2001.

[17] Armstrong D. W., "A new class of chiral selectors for enantiomeric separations by LC, TLC, GC, CE and SFC," in Proceedings of the Pittsburg Conference Abstracts, p. 572, Pittconn, 1994.

[18] D. W. Armstrong and U. B. Nair, "Capillary electrophoretic enantioseparations using macrocyclic antibiotics as chiral selectors," Electrophoresis, vol. 18, no. 12-13, pp. 2331-2342, 1997.

[19] T. J. Ward and T. M. Oswald, "Enantioselectivity in capillary electrophoresis using the macrocyclic antibiotics," Journal of Chromatography A, vol. 792, no. 1-2, pp. 309-325, 1997.

[20] M. P. Gasper, A. Berthod, U. B. Nair, and D. W. Armstrong, "Comparison and modeling study of vancomycin, ristocetin A, and teicoplanin for CE enantioseparations," Analytical Chemistry, vol. 68, no. 15, pp. 2501-2514, 1996.

[21] T. J. Ward, C. Dann, and A. Blaylock, "Enantiomeric resolution using the macrocyclic antibiotics rifamycin B and rifamycin SV as chiral selectors for capillary electrophoresis," Journal of Chromatography A, vol. 715, no. 2, pp. 337-344, 1995.

[22] T. J. Ward, "Macrocyclic antibiotics - the newest class of chiral selectors," LC GC, vol. 14, no. 10, pp. 886-894, 1996.

[23] K. Ren, "Selectivity problems of membrane ion-selective electrodes: a method alternative to the IUPAC recommendation and its application to the selectivity mechanism investigation," Fresenius' Journal of Analytical Chemistry, vol. 365, no. 5, pp. 389-397, 1999.

[24] I. D. P. Wootton, Micro-Analysis in Medical Biochemistry, J. A. Chuchill Ltd., London, UK, 4th edition, 1964. 


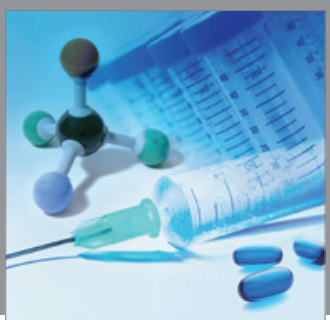

International Journal of

Medicinal Chemistry

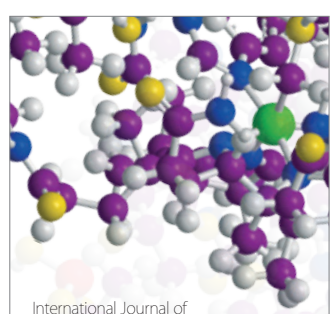

Carbohydrate Chemistry

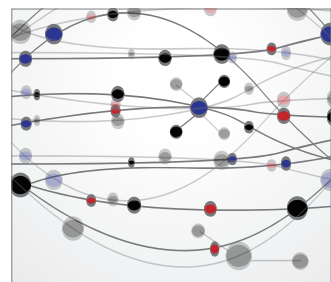

The Scientific World Journal
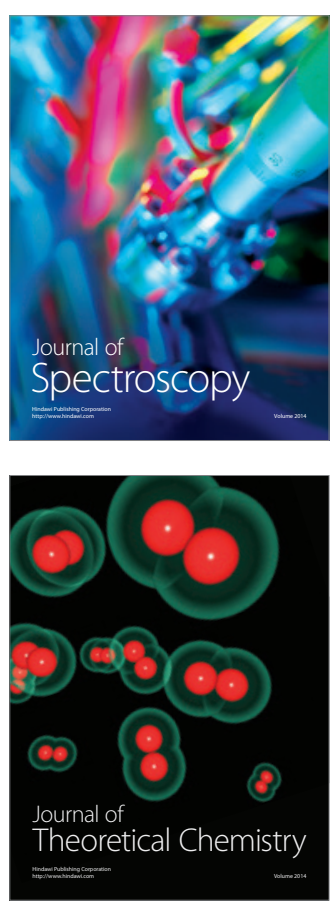
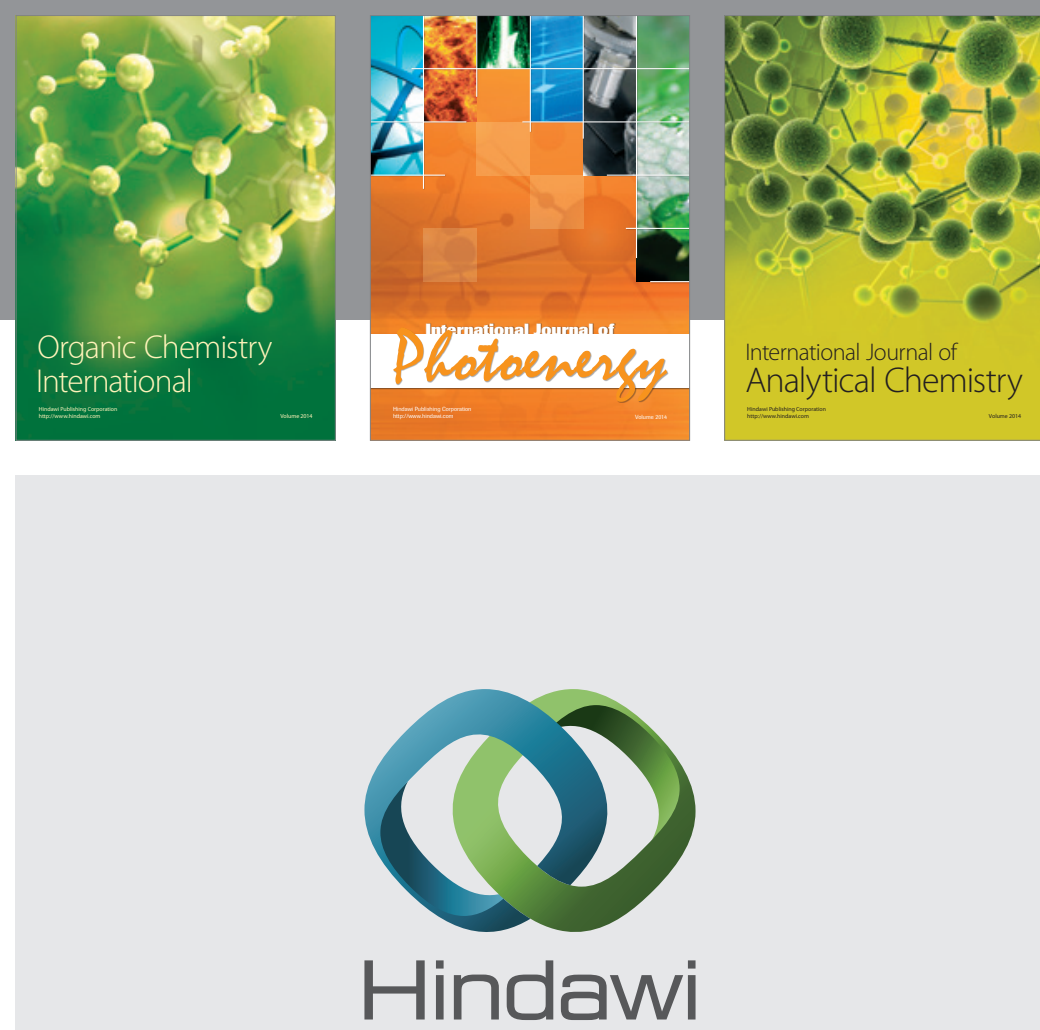

Submit your manuscripts at

http://www.hindawi.com
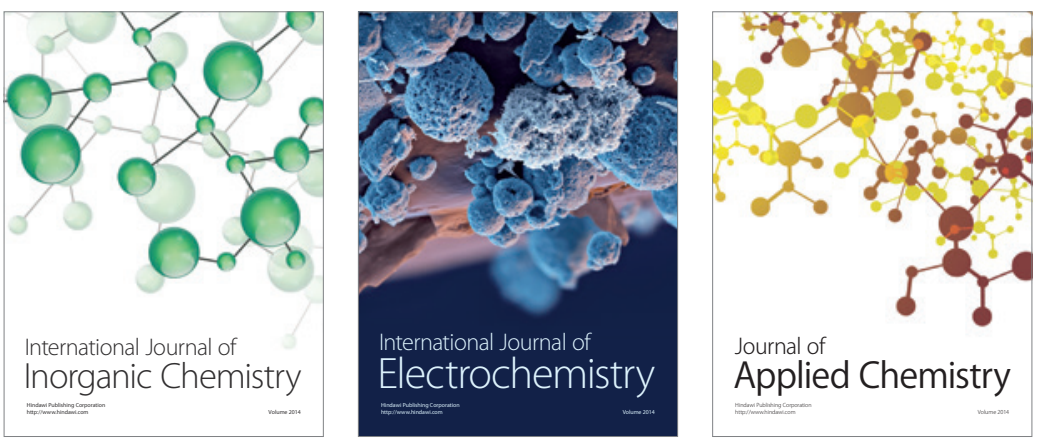

Journal of

Applied Chemistry
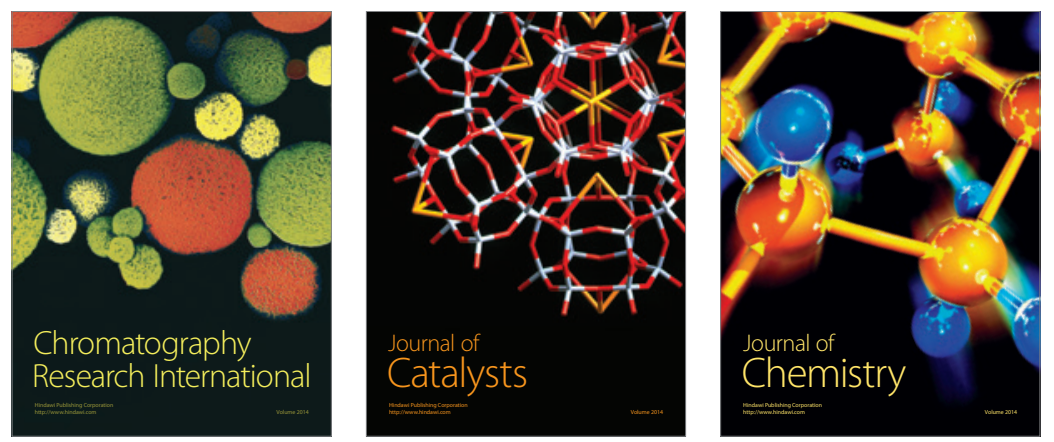
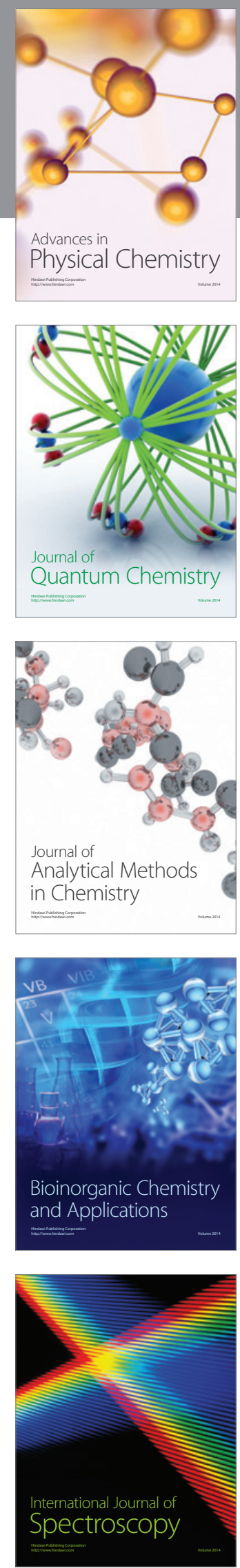